Mubarok, S. · A. Mardatillah · A. Nuraini

\title{
Pertumbuhan dan hasil dua kultivar bayam pada sistem budidaya hidroponik untuk lahan sempit
}

Sari Hidroponik merupakan salah satu teknik sistem budidaya yang biasa digunakan di lahan sempit seperti di perkotaan. Tujuan dari penelitian ini adalah untuk menentukan sistem budidaya bayam yang paling baik untuk diterapkan pada sistem urban farming pada lahan sempit, misalnya di kawasan pemukiman padat penduduk di bagian timur Jakarta. Rancangan Acak Kelompok Lengkap yang digunakan dalam penelitian ini terdiri dari dua kultivar bayam dan tiga sistem budidaya yaitu budidaya konvensional, sistem hidroponik Wick dan NFT. Hasil penelitian menunjukkan bahwa sistem NFT menghasilkan pertumbuhan dan hasil terbaik yang ditunjukkan oleh jumlah daun, diameter batang, luas daun, panjang akar, volume akar dan berat segar tanaman yang lebih baik daripada sistem hidroponik Wick dan konvensional pada dua kultivar bayam 'Maestro' dan 'Mira'.

Kata kunci: Bayam $\cdot$ Kemandirian pangan $\cdot$ Lahan pekarangan $\cdot$ NFT $\cdot$ Wick

\section{Growth and yield of two amaranth cultivars in hydroponic cultivation systems for small agricultural lands}

\begin{abstract}
Hydroponic is one of the cultivation system techniques that usually used in the small area alike urban area. The purpose of this study was to determine the best amaranth cultivation system to be applied in urban farming system applied on small area, e.g. in a densely inhabited residental area in eastern part of Jakarta. Randomized Completely Block Design used in this experiment consisted of two amaranth cultivars and three cultivation systems namely conventional cultivation, Wick hydroponic and NFT hydroponic. The results showed that the NFT system resulted the best growth and yield, as indicated by the number of leaves, stem diameter, leaf area, root length, root volume and plant fresh weight that were better than the Wick hydroponic and conventional system in two amaranth cultivars namely 'Maestro' and 'Mira'.
\end{abstract}

Keywords: Amaranth $\cdot$ Food independence $\cdot$ Yard $\cdot$ NFT $•$ Wick

Diterima : 7 Mei 2021, Disetujui : 8 Desember 2021, Dipublikasikan : 15 Desember 2021

DOI: $10.24198 /$ kultivasi.v20i3.32141

\footnotetext{
Mubarok, S. ${ }^{1}$ A. Mardatillah' ${ }^{2}$ A. Nuraini ${ }^{1}$

${ }^{1}$ Departemen Budidaya Pertanian, Fakultas Pertanian UNPAD, Jalan Raya Bandung Sumedang Km. 21 Sumedang 45363

2 Program Studi Agroteknologi, Fakultas Pertanian UNPAD, Jalan Raya Bandung Sumedang Km. 21 Sumedang 45363

Korespondensi: syariful.mubarok@unpad.ac.id
} 


\section{Pendahuluan}

Lahan pekarangan memiliki potensi sebagai penyedia bahan pangan keluarga, mengurangi pengeluaran rumah tangga, dan meningkatkan pendapatan keluarga (Ashari et al., 2012). Kementerian Pertanian Repulik Indonesia (Kementan RI) selaku sektor yang bertanggung jawab terhadap penyediaan pangan, telah menyiapkan berbagai strategi salah satunya melalui Program Pekarangan Pangan Lestari (Kementan RI, 2020). Keterbatasan lahan produktif menjadi kendala dalam pengembangan pertanian di perkotaan seperti di DKI Jakarta. Namun, hal tersebut dapat diatas dengan penerapan pertanian perkotaan salah satunya pemanfaatan lahan sempit (Deputi Gubernur DKI Jakarta, 2018).

Pemanfaatan lahan sempit seperti pekarangan dapat menjadi sumber potensial penyedia bahan pangan yang bernilai gizi serta ekonomis apabila ditata dan dikelola dengan baik (Erawati et al., 2014). Budidaya di lahan pekarangan memerlukan perhatian pada sejumlah aspek, diantaranya jenis sistem budidaya yang akan diterapkan dan penentuan komoditas. Sistem budidaya yang dapat diterapkan pada lahan pekarangan adalah sistem budidaya konvensional yang menggunakan media tanah dalam polybag serta sistem hidroponik yang menggunakan media tanpa tanah. Pada penelitian sebelumnya, teknik budidaya melalui hidroponik rakit apung dapat meningkatkan pertumbuhan dan hasil budidaya bayam di lahan sempit Bekasi (Mubarok et al., 2021). Sistem budidaya lahan sempit dapat menghemat penggunaan lahan tanpa mengurangi produktivitas tanaman (Pasir dan Hakim, 2013; Sarido et al., 2017). Selain sistem rakit apung, sistem Nutrient Film Technique (NFT) dan Wick merupakan sistem yang umum digunakan dalam budidaya tanaman dengan metode hidroponik (Aires, 2018).

Penentuan komoditas tentunya harus disesuaikan dengan kondisi lingkungan tumbuh sekitar. Daerah Khusus Ibukota Jakarta termasuk ke dalam dataran rendah dengan ketinggian rata-rata $7 \mathrm{~m}$ diatas permukaan laut (dpl). Di satu sisi, bayam (Amaranthus sp.) merupakan tanaman yang memiliki daya adaptasi yang tinggi pada berbagai ekosistem (Zuryanti et al., 2016), sehingga bayam dapat menjadi pilihan komoditas untuk dibudidayakan di dataran rendah seperti di DKI Jakarta. Bayam hijau dan merah merupakan jenis bayam yang umum dikonsumsi. Kultivar Mira dan Maestro masing-masing merupakan kultivar bayam merah dan hijau yang umum digunakan dalam budidaya tanaman (Ghifari et al., 2019). Penelitian ini bertujuan untuk mengetahui sistem hidroponik semacam apa yang baik digunakan untuk tanaman bayam Kultivar Maestro dan Mira yang di tanam di daerah DKI Jakarta.

\section{Bahan dan Metode}

Dua kultivar tanaman bayam, 'Maestro' dan 'Mira', ditumbuhkan pada sistem budidaya konvensional dan hidroponik Wick dan hidroponik NFT yang menggunakan Rancangan Acak Kelompok (RAK) dan diulang sebanyak enam belas kali ulangan. Penanaman dilakukan di daerah Kemanggisan Ilir, Jakarta Barat dengan ketinggian tempat $\pm 7 \mathrm{~m}$ dpl. Pada setiap satuan percobaan terdapat lima polybag (konvensional) atau netpot (hidroponik) yang berisi masing-masing 3 bibit tanaman bayam. Tahapan penelitian meliputi persemaian, penanaman, pemupukan, pemeliharaan, dan pemanenan.

Parameter pengamatan yang diamati antara lain jumlah daun per tanaman, tinggi tanaman, diameter batang, luas daun, panjang akar, volume akar, dan berat segar per tanaman. Pengaruh perlakuan terhadap pertumbuhan dan hasil tanaman bayam dianalisis dengan analisis ragam uji $\mathrm{F}$ pada taraf kepercayaan $95 \%$ dan apabila terdapat perbedaan antar perlakuan akan dilanjutkan dengan analisis uji Tukey (HSD) pada taraf kepercayaan 95\%.

\section{Hasil dan Pembahasan}

Tinggi Tanaman dan diameter batang. Teknologi budidaya hidroponik dengan sistem Wick dan NFT mampu menghasilkan pertumbuhan tanaman yang baik ditandai dengan penampilan tanaman yang segar (Gambar 1). Berdasarkan hasil analisis statistik menggunakan uji Tukey pada taraf nyata 5\% menunjukkan bahwa sistem budidaya konvensional, hidroponik NFT, dan hidroponik Wick berpengaruh terhadap tinggi tanaman bayam Kultivar Maestro dan Mira pada umur 15 
hari setelah pindah tanam (HSPT). Tinggi tanaman dan diameter batang bayam pada budidaya konvensional merupakan yang terendah dibandingkan dengan dua sistem lainnya. Sistem Wick menghasilkan tinggi tanaman tertinggi pada kultivar Maestro dan Mira dengan nilai masing-masing 27,31 dan 19,69 yang tidak berbeda nyata dibandingkan dengan sistem NFT (Gambar 2).

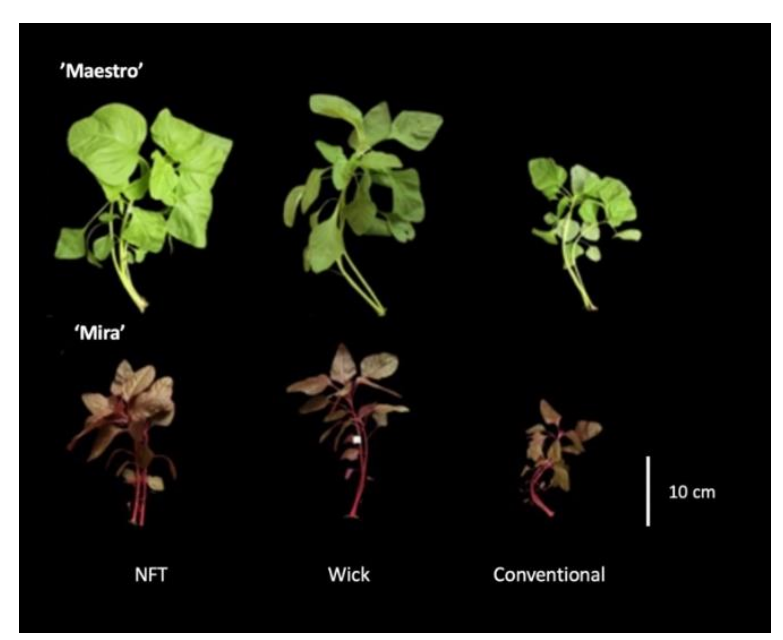

Gambar 1. Penampilan tanaman bayam pada umur 15 HSPT
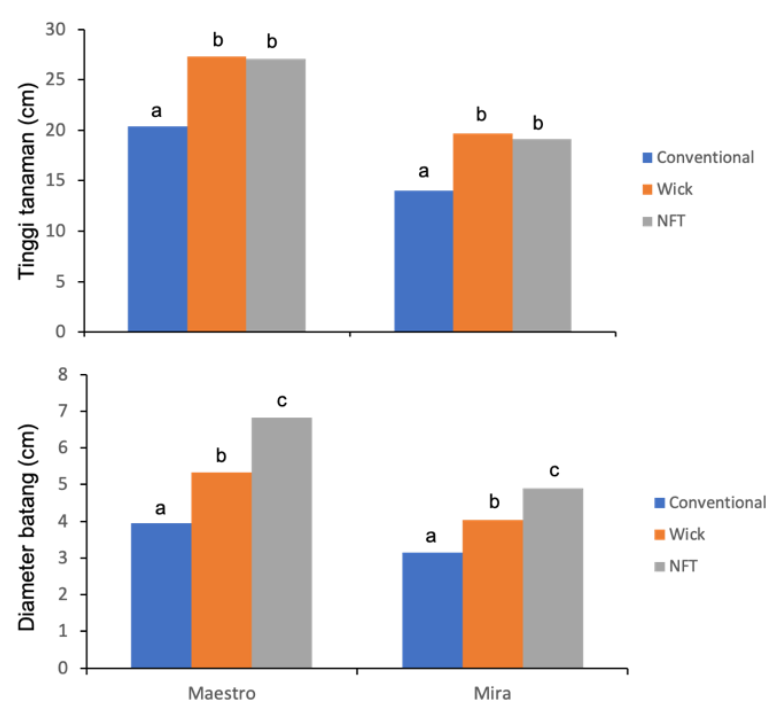

Gambar 2. Pengaruh tiga sistem budidaya terhadap tinggi tanaman dan diameter batang bayam Kultivar Maestro dan Mira pada umur 15 HSPT. Angka yang diikuti dengan huruf yang sama pada setiap kultivar menunjukkan tidak berbeda nyata berdasarkan uji Tukey pada taraf nyata $5 \%$.

Pengaruh jenis sistem budidaya menunjukkan adanya perubahan terhadap diameter batang bayam pada kedua kultivar. Tanaman yang ditanam pada sistem NFT baik bayam 'Maestro' ataupun 'Mira' menghasilkan diameter batang tertinggi dibandingkan dengan sistem Wick ataupun konvensional dengan nilai diameter batang masing-masing 6,82 dan 4,91 mm.

Jumlah Daun dan Luas Daun. Berdasarkan hasil analisis statistik menggunakan uji Tukey pada taraf nyata $5 \%$ menunjukkan bahwa NFT menghasilkan jumlah daun dan luas daun tertinggi pada kedua kultivar, dengan jumlah daun adalah 19,81 untuk 'Maestro' dan 14,50 untuk 'Mira', sedangkan untuk luas daun masing-masing adalah 498,41 $\mathrm{cm}^{2}$ dan 298,37 $\mathrm{cm}^{2}$, yang berbeda nyata bila dibandingkan dua sistem lainnya, yaitu konvensional dan Wick sistem (Gambar 3).
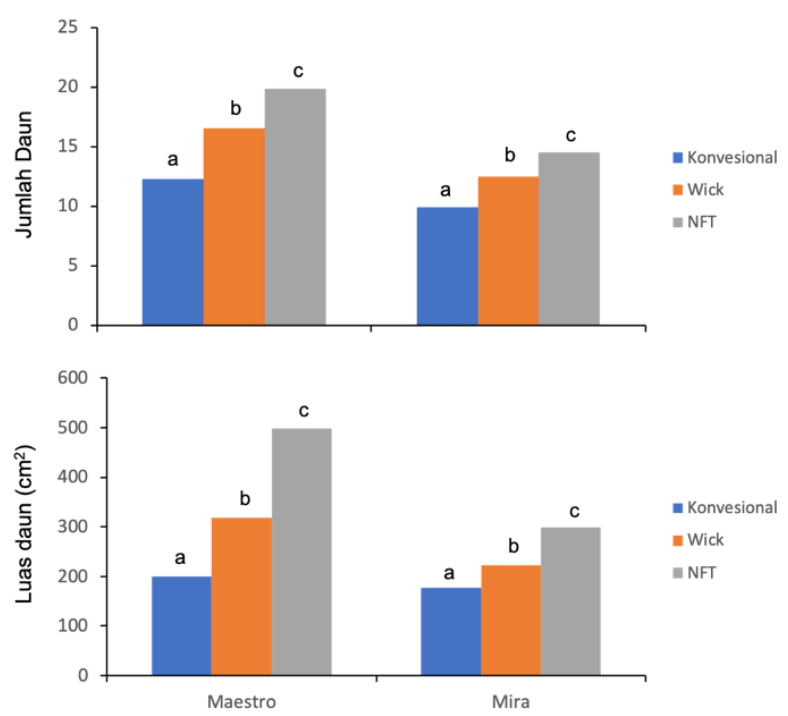

Gambar 3. Pengaruh perlakuan sistem budidaya terhadap jumlah daun tanaman bayam Kultivar Maestro dan Mira.

Panjang Akar dan Volume Akar. Berdasarkan hasil analisis statistik menggunakan uji Tukey pada taraf nyata 5\% menunjukkan bahwa sistem budidaya berpengaruh terhadap panjang dan volume akar bayam 'Maestro' dan 'Mira' yang ditanam di daerah DKI Jakarta. Sistem NFT memberikan peningkatan panjang akar dan volume akar yang signifikan bila dibandingkan dengan dua sistem lainnya, dengan panjang akar 33,18 cm dan 29,01 cm masing-masing untuk kultivar Maestro dan Mira, sedangkan untuk volume akar yaitu 16,03 $\mathrm{mL}$ dan $15,94 \mathrm{~mL}$ masing-masing untuk kultivar Maestro dan Mira (Gambar 4). 

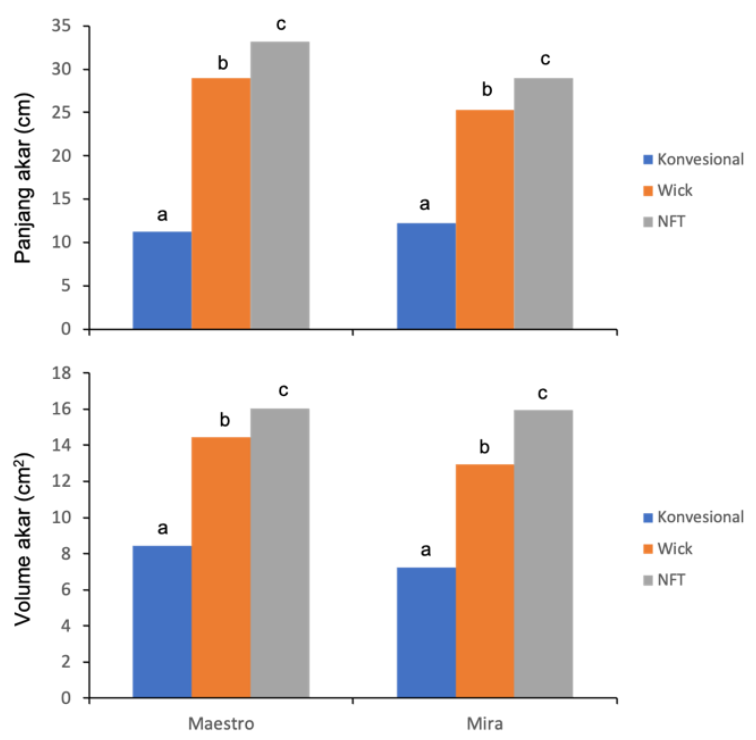

Gambar 4. Pengaruh perlakuan sistem budidaya terhadap panjang akar tanaman bayam Kultivar Maestro dan Mira.

Berat Segar Tanaman. Berdasarkan hasil analisis ragam diperoleh bahwa perlakuan sistem budidaya konvensional, hidroponik NFT dan hidroponik Wick berpengaruh terhadap bobot segar bayam Kultivar Maestro dan Mira. Sistem hidroponik NFT menghasilkan tanaman bayam dengan hasil paling tinggi dibandingkan dengan sistem konvensional dan Wick dengan bobot 47,06 g dan 36,56 g masing-masing untuk bayam kultivar Maestro dan Mira (Gambar 5).

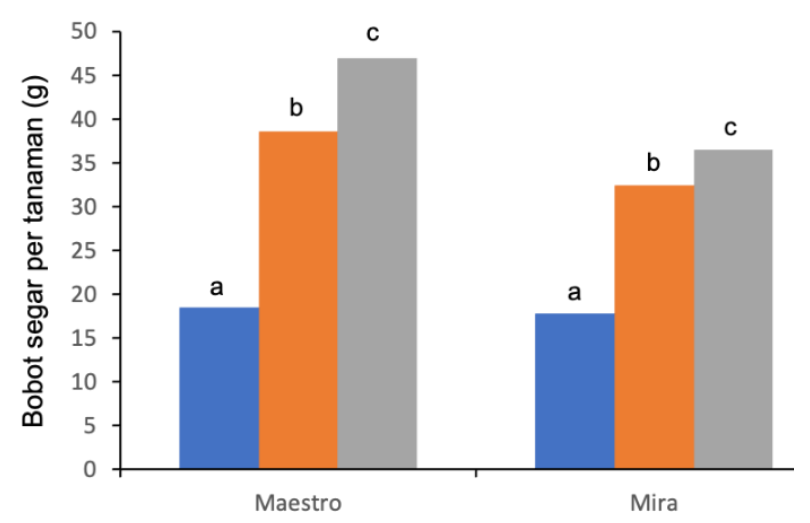

Gambar 5. Pengaruh perlakuan sistem budidaya terhadap berat segar tanaman bayam Kultivar Maestro dan Mira.

Budidaya bayam Kultivar Maestro dan Mira dengan perlakuan sistem hidroponik NFT memberikan pertumbuhan dan hasil yang paling baik dibandingkan dengan sistem konvensional dan Wick. Hal ini disebabkan kebutuhan hara, air, dan aerasi pada sistem hidroponik NFT terpenuhi dengan baik. Instalasi hidroponik NFT dirakit dengan kemiringan tertentu sehingga larutan hara dapat mengalir dengan kecepatan sesuai dengan kemiringannya serta sirkulasi yang terjadi secara berulang pada sistem hidroponik NFT memenuhi kebutuhan tanaman akan hara dan oksigen (Surtinah, 2016). Hal serupa ditunjukkan oleh Febriani et al. (2012) yang menyatakan bahwa hidroponik NFT mampu memenuhi kebutuhan oksigen tanpa bantuan aerasi tambahan dikarenakan pemberian aerasi secara terus menerus maupun tidak diberikan aerasi menghasilkan hasil pertanaman yang relatif sama.

Hidayat et al. (2013) menyatakan bahwa ketersediaan hara, air, dan aerasi merupakan faktor yang berpengaruh terhadap pertumbuhan akar. Kandungan oksigen di dalam media tanam berperan penting dalam proses respirasi tanaman. Apabila kandungan oksigen pada media tanam tidak terpenuhi maka proses respirasi akan terhambat. Hal ini mengakibatkan penurunan kemampuan tanaman dalam penyerapan air dan hara oleh akar (Novitasari, 2017). Pada sistem hidroponik NFT kebutuhan hara, air, dan aerasi tersedia dengan baik. Hal ini ditunjukkan pada panjang akar dan volume akar bayam Kultivar Maestro dan Mira pada sistem hidroponik NFT lebih baik bila dibandingkan dengan sistem konvensional dan Wick (Gambar4). Sitompul dan Guritno (1995) serta Hidayat et al. (2013) menyatakan bahwa panjang akar dan volume akar merupakan tolak ukur kemampuan tanaman terhadap daya serap air dan hara.

Ketersediaan hara dan air yang mencukupi berpengaruh terhadap peningkatan laju fotosintesis. Pertumbuhan dan pembentukan organ vegetatif tanaman seperti diameter batang dan daun dipengaruhi oleh laju fotosintesis (Polii, 2009; Susilawati, 2016). Ifantri dan Ardiyanto (2015) menyatakan bahwa pertambahan jumlah daun akan sejalan dengan luas daun yang akan berpengaruh terhadap peningkatan berat segar tanaman. Daun merupakan organ tanaman sayuran yang memiliki kandungan air yang tinggi sehingga apabila jumlah daun meningkat maka kadar air akan meningkat. Kadar air yang meningkat sejalan dengan peningkatan berat segar tanaman (Polii, 2009).

Sistem Wick menghasilkan pertumbuhan yang kurang baik dibandingkan dengan sistem NFT. Hal ini selaras dengan pernyataan Aires 
(2018) yang menyatakan bahwa sistem hidroponik Wick memiliki tingkat oksigen yang rendah pada zona perakaran akibat tidak adanya sirkulasi pada larutan hara. Hal ini diduga menjadi penyebab pertumbuhan dan berat segar tanaman bayam Kultivar Maestro dan Mira pada sistem hidroponik Wick lebih rendah jika dibandingkan dengan sistem hidroponik NFT. Sama halnya pada sistem hidroponik rakit apung, akibat tidak adanya sirkulasi menyebabkan terbatasnya konsentrasi oksigen di larutan hara (Carrasco et al., 2011). Hasil penelitian Surtinah (2016) menyatakan bahwa tanaman pakcoy yang ditanam pada media tanam yang diberi oksigen memberikan hasil pertumbuhan yang lebih baik dibandingkan dengan tanpa pemberian oksigen. Hal tersebut menunjukkan bahwa kandungan oksigen berperan penting pada media tanam, termasuk dalam proses respirasi tanaman. Tanaman akan melangsungkan respirasi secara anaerob pada keadaan kekurangan oksigen, yang mana energi yang dihasilkan sangat sedikit. Dalam jangka panjang kekurangan oksigen akan menyebabkan pertumbuhan tanaman terhambat akibat tidak terpenuhinya energi untuk aktifitas pertumbuhan tanaman (Novitasari, 2017). Steinberg et al. (2000) menyatakan bahwa sistem budidaya konvensional memiliki kemampuan menjaga air, hara dan, aerasi di zona perakaran yang lebih rendah jika dibandingkan dengan sistem hidroponik NFT. Hal ini didukung oleh pernyataan Siswadi (2008) bahwa ketersediaan hara pada sistem budidaya konvensional bergantung pada kemampuan tanah dalam menyediakan unsur hara.

Budidaya bayam Kultivar Maestro dan Mira dengan sistem budidaya konvensional menggunakan fertigasi secara manual, sedangkan sistem hidroponik Wick dan hidroponik NFT menggunakan fertigasi secara otomatis. Izzati (2006) menyatakan bahwa fertigasi secara otomatis memberikan hasil efektif pada peningkatan pertumbuhan dan produksi tanaman selada dibandingkan fertigasi secara manual. Hal serupa diungkapkan Iqbal (2006) yang menyatakan bahwa fertigasi secara manual memberikan hasil berat segar bayam lebih rendah dibandingkan dengan fertigasi secara otomatis.
1. Terdapat pengaruh perbedaan sistem budidaya, yaitu sistem budidaya konvensional, hidroponik NFT dan hidroponik Wick, terhadap pertumbuhan dan berat segar bayam Kultivar Maestro dan Mira pada lahan sempit pekarangan di DKI Jakarta. Sistem budidaya hidroponik menggunakan Wick dan NFT menunjukkan adanya peningkatan pada parameter tinggi tanaman, diameter batang, jumlah daun, panjang akar, volume akar, luas daun dan berat segar tanaman.

2. Budidaya bayam Kultivar Maestro dan Mira pada sistem hidroponik NFT memberikan hasil pertumbuhan dan berat segar tanaman lebih baik, ditunjukkan pada parameter diameter batang, jumlah daun, panjang akar, volume akar, dan luas daun, sementara sistem budidaya konvensional memberikan pertumbuhan dan berat segar tanaman terendah.

\section{Daftar Pustaka}

Aires, A. 2018. Hydroponic Production Systems: Impact on Nutritional Status and Bioactive Compounds of Fresh Vegetables. Vegetables: Importance of Quality Vegetables to Human Health, pp. 55.

Ashari, S. dan T.B. Purwantini. 2012. Potensi dan prospek pemanfaatan lahan pekarangan untuk mendukung ketahanan pangan. Forum Penelitian Agro Ekonomi. 30 (1): 1330.

Carrasco, G., J.M. Gajardo, J.E. Álvaro dan M. Urrestarazu. 2011. Rocket Production (Eruca sativa Mill.) in a Floating System Using Peracetic Acid as Oxygen Source Compared with Substrate Culture. Journal of Plant Nutrition 34(9): 1397-1401.

Deputi Gubernur DKI Jakarta. 2018. Desain Besar Pertanian Perkotaan Provinsi DKI Jakarta Tahun 2018 - 2030. Jakarta. 40p.

Erawati, B.T.R., Y. Triguna, A. Hipi, dan Rosdiana. 2014. Peran Perkarangan Dalam Meningkatkan Pendapatan Keluarga Untuk Mendukung Ketahanan Pangan di Kabupaten Lombok Barat Nusa Tenggara Barat. Seminar Nasional Gorontalo 1(1): 205-212.

\section{Kesimpulan}


Febriani, D.N.S., D. Indradewa dan S. Waluyo. 2012. Pengaruh Pemotongan Akar dan Lama Aerasi Media terhadap Pertumbuhan Selada (Lactuca sativa L.) Nutrient Film Technique. Vegetalika 1(1): 123-134.

Ghifari, A.F., R. Mochammad, dan Koesriharti. 2019. Pengaruh Dosis Pupuk Majemuk NPK Terhadap Hasil dan Kandungan Vitamin C Dua Varietas Bayam (Amaranthus tricolor L.). Jurnal Produksi Tanaman 7(10): 1780-1788.

Hidayat, T., Wardawati, dan Armaini. 2013. Pertumbuhan dan Produksi Sawi (Brassica juncea L) Pada Inceptisol dengan Aplikasi Kompos Tandan Kosong Kelapa Sawit. Doctoral dissertation. Universitas Riau. Riau

Ifantri, J. dan Ardiyanto. 2015. Pengaruh Jumlah Daun dan Jenis Pupuk Kandang terhadap Pertumbuhan dan Hasil Melon (Cucumis melo L.). Universitas PGRI Yogyakarta. Yogyakarta.

Iqbal, M. 2006. Penggunaan Pupuk Majemuk Sebagai Sumber Hara pada Budidaya Bayam Secara Hidroponik dengan Tiga Fertigasi. Skripsi. Departemen Agronomi dan Hortikultura. Fakultas Pertanian. Institut Pertanian Bogor. Bogor.

Izzati, I.R. 2006. Penggunaan Pupuk Majemuk sebagai Sumber Hara pada Budidaya Selada (Lactuca sativa L.) secara Hidroponik dengan Tiga Cara Fertigasi. Skripsi. Departemen Agronomi dan Hortikultura. Fakultas Pertanian. Institut Pertanian Bogor. Bogor.

Kementrian Pertanian Republik Indonesia. 2020. Kementan Siapkan Strategi Pangan di Tengah Pandemi Covid-19.

Mubarok, S., S.D. Ananda, Farida, A. Fadilah, dan R. Sudirja. 2021. Evaluasi tiga sistem budidaya di lahan sempit pada budidaya dua kultivar bayam di kota Bekasi. Jurnal Kultivasi 20(2): 73-81
Novitasari, R. 2017. Proses Respirasi Seluler Pada Tumbuhan. Prosiding Seminar Nasional Pendidikan Biologi, 1: 89-96.

Pasir, S. dan M.S. Hakim. 2014. Penyuluhan Penanaman Sayuran Dengan Media Polybag. Jurnal Inovasi dan Kewirausahaa 3(3). ISSN : 2089-3086.

Polii, M.G.M. 2009. Respon Produksi Tanaman Kangkung terhadap Variasi Waktu Pemberian Pupuk Kotoran Ayam. Soil Environment, (7) $1: 18$ - 22.

Sarido, L., dan Junia. 2017. Uji Pertumbuhan dan Hasil tanaman Pakcoy dengan Pemberian Pupuk Organik Cair Pada Sistem Hidroponik. Jurnal Agrifor 16(1): 65-74

Siswadi. 2008. Berbagai Formulasi Kebutuhan Nutrisi Pada Sistem Hidroponik. Jurnal Inovasi Pertanian 7(1): 103-110.

Sitompul, S. M. dan B. Guritno. 1995. Analisis Pertumbuhan Tanaman. Yogyakarta : UGM. Press. Yogyakarta.

Steinberg, S.L., W.M. Douglas, K.E. Henderson, C. Carrier, J.E. Gruener, J.D.J. Barta dan D.L. Henninger. 2000. Wheat Response to Difference in Water and Nutritional Status Between Zeoponic and Hydroponic Growth Systems. Agron J 92: 353-360.

Surtinah. 2016. Penambahan Oksigen Pada Media Tanam Hidroponik Terhadap Pertumbuhan Pakcoy (Brassica rapa). Jurnal Bibiet 1(1): 27-35.

Susilawati, S., W. Wardah, dan I. Irmasari. 2016. Pengaruh Berbagai Intensitas Cahaya Terhadap Semai Cempaka (Michelia champca L.) di Persemaian. Forest Sains 14(1): 59-66.

Zuryanti, D., A. Rahayu, dan N. Rochman. 2016. Pertumbuhan, Produksi dan Kualitas Bayam (Amaranthus tricolor L.) Pada berbagai Dosis Pupuk Kandang Ayam dan Kalium Nitrat $\left(\mathrm{KNO}_{3}\right)$. Jurnal Agronida 2(2): 99-105. 